Jurnal Ekonomi dan Bisnis, Vol. 8 No. 2 September 2021

P - ISSN : :2503-4413

E - ISSN : 2654-5837, Hal $122-130$

\title{
KONTRIBUSI PROFITABILITAS TERHADAP PERTUMBUHAN LABA PT. BANK RAKYAT INDONESIA (PERSERO), TBK
}

\author{
Oleh: \\ Wulan Purnama Rais, Nur Fiskayani yustika, Adhe Alda Rezky Darmawan \\ Jurusan Manajemen - STIEM Bongaya Makassar. \\ E-mail : wulanrais12@gmail.com; adhealda@gmail.com; nurfiskayaniy@gmail.com \\ Muhammad Irfai Sohilauw \\ Jurusan Manajemen - STIEM Bongaya Makassar. \\ E-mail : sohilauw1899@gmail.com
}

\begin{tabular}{|c|c|}
\hline Article Info & Abstract \\
\hline $\begin{array}{l}\text { Article History : } \\
\text { Received } 23 \text { August - } 2021 \\
\text { Accepted 03 Sept - } 2021 \\
\text { Available Online } 25 \text { Sept - } \\
2021\end{array}$ & $\begin{array}{l}\text { The purpose of this study is to examine and evaluate the impact of } \\
\text { return on assets (ROA), return on equity (ROE), and net profit } \\
\text { margin (NPM) on PT. Bank Rakyat Indonesia (Persero), Tbk's } \\
\text { profit growth. The method of explanatory analysis with a } \\
\text { quantitative approach is used in this study. From } 2010 \text { to } 2019 \text {, } \\
\text { secondary data were analyzed quarterly, yielding } 40 \text { observations. } \\
\text { The data was analyzed with Microsoft Excel } 2013 \text { and SPSS } \\
\text { Version } 21 \text {. Using multiple linear regression analysis, Return On } \\
\text { Assets (ROA)/XI had a negative and insignificant effect on Profit } \\
\text { Growth (Y) of PT. Bank Rakyat Indonesia (Persero), Tbk from } \\
2010 \text { to 2019. However, Return On Assets (ROE) /X } 2 \text { and Net } \\
\text { Profit Margin (NPM) /X3 have a positive and significant impact } \\
\text { on Changes in Profit (Y) PT. Bank Rakyat Indonesia (Persero), } \\
\text { Tbk from } 2010 \text { to 2019. }\end{array}$ \\
\hline $\begin{array}{l}\text { Keyword: } \\
\text { Return On Asset, Return On } \\
\text { Equity, Net Profit Margin, } \\
\text { Profit Growth }\end{array}$ & \\
\hline
\end{tabular}

\section{PENDAHULUAN}

Perkembangan perekonomian di indonesia saat ini mendorong Bank Rakyat Indonesia untuk meningkatkan kinerja perusahaannya. Tingginya persaingan bisnis antar Bank, Ditambah lagi adanya pergantian trend, perubahan gaya hidup, kemajuan teknologi yang pesat menyebabkan Bank Rakyat Indonesia harus mampu beradaptasi dalam mempertahankan bisnisnya. Walau demikian, Bank Rakyat Indonesia tetap mampu bersaing. Hal ini ditandai dengan diberikannya pengargaan Banking Award kategori "Sehat" pada Banking Awards 2019.(PT Bank Rakyat Indonesia, 2019), serta Bank bertajuk "Bank
Terpercaya 2019”. Selain itu, Bank dengan Aset terbesar dan jaringan layanan terluas ini terus berinovasi, diantaranya meluncurkan satelit layanan sendiri BRi-Sat, mengoptimalkan nasabah sebagai agen penjualan BRI-link, peluncuran Teras BRI (Kapal), dan berbagai inovasi lainnya (PT Bank Rakyat Indonesia, 2019). Tentu saja, kondisi ini membuat kepercayaan investor meningkat untuk menanamkan modalnya.

Namun, prestasi diatas masih menyisakan masalah yang serius. Tingginya ekspansi bisnis, tidak dimbangi dengan pemanfaatan sumber daya dengan baik. Dengan demikian, profitabilitas 
perusahaan medio 2016-2019 cenderung turun. Berdasarkan data pada tabel 1, kita dapat melihat bahwa laba bersih meningkat sebesar 34,4 triliun dari 2016 ke 2019 dan ROA turun 3,50\% dari 2016 ke 2019. ROE turun 19, 1\% dari 2016 ke 2019. Dalam kasus NPM, meningkat sebesar $28,26 \%$ dari tahun 2016 hingga 2019. Oleh karena itu, terlihat jelas masih ada fluktuasi profitabilitas Bank Rakyat Indonesia. Fakta empiris lainnya yang membuat tergerusnya laba perusahaan adalah akuisisi Danareksa Sekuritas untuk mengembangkan transaksi ritel dan korporasi, serta akuisisi Modal Ventura Bahana untuk mengembangkan bisnis fintech dan startup (PT Bank Rakyat Indonesia, 2019).

\section{Tabel 1 Keadaan Pertumbuhan Laba, ROA, ROE dan NPM Bank Rakyat Indonesia}

\begin{tabular}{|c|c|c|c|c|}
\hline Tahun & $\begin{array}{c}\text { Pertumbuhan } \\
\text { Laba }\end{array}$ & ROA & ROE & NPM \\
\hline 2016 & 3,20 & $3,84 \%$ & $23,08 \%$ & $27,90 \%$ \\
\hline 2017 & 10,70 & $3,69 \%$ & $20,03 \%$ & $28,22 \%$ \\
\hline 2018 & 3,20 & $3,68 \%$ & $20,49 \%$ & $26,62 \%$ \\
\hline 2019 & 6,10 & $3,50 \%$ & $19,41 \%$ & $28,26 \%$ \\
\hline
\end{tabular}

Sumber : Laporan Keuangan BRI (diolah, 2021)

Kinerja perusahan dapat dikatakan baik jika profitabilitas meningkat. Kondisi ini akan meningkatkan value perusahaan di mata masyarakat (Kusuma, Suhadak, \& Arifin, 2019), dikarenakan baik tidaknya sebuah perusahan perusahaan (terutama perusahan jasa) sangat tergantung dari penilaian customernya. Ketika penilaian baik, maka seorang customer akan loyal terhadap apapun produk dari perusahaan tersebut (Ainun, Murtani, \& Hutagalung, 2020) . Manajemen selalu dituntut untuk meningkatkan nilai perusahaan. Mandat yang diberikan oleh stakeholder wajib untuk dijalankan dengan baik (Jensen \& Meckling, 1976). Dengan demikian, Value perusahaan akan tetap terga dengan baik.

Diantara factor yang menyebabkan value perusahaan meningkat adalah pertumbuhan laba (Likha \& Fitria, 2019). Pertumbuhan laba merupakan selisih antara laba tahun ini dengan laba tahun lalu dibagi dengan laba tahun lalu.(Likha \& Fitria, 2019). Karena tujuan setiap perusahaan adalah memaksimumkan keuntungan, maka sudah barang tentu manajemen wajib memperhatikan factor-faktor apa saja yang menjadi penyebabnya, diantaranya Net Profit Margin (NPM) DAN Pertumbuhan Laba. (Putriana, 2016), serta Likuiditas dan Profitabilitas (Fadella, Dewi, \& Fajri, 2020).

Profitabilitas adalah kemampuan untuk menghasilkan keuntungan melalui bisnis menggunakan dana ekuitas milik perusahaan (Kusuma et al., 2019). Karena tujuan operasi beberapa perusahaan adalah untuk memaksimalkan keuntungan, peran manajemen diperlukan untuk meningkatkan keuntungan pemiliknya. (Septiani, Siswantini, \& Murtatik, 2021). Rasio ini diproksikan sebagai return on assets/ROA (rasio kemampuan bank dalam menghasilkan keuntungan dari penggunaan aset) (Asnawi, Rate, Sam, \& Manado, 2018); Return on Equity / ROE, mengukur keuntungan yang dihasilkan oleh perusahaan dalam kaitannya dengan modal yang dikeluarkan oleh pemegang sahamnya (Ikhwal, 2016) dan Net Profit Margin I NPM adalah kemampuan bisnis untuk beroperasi pada laba bersih dari setiap penjualan (Fadila \& Saifi, 2018).

Dalam tulisan ini, peneliti berfokus pada aspek profitabilitas (return on assets/ROA, return on equity/ROE, net margin/NPM) karena ketiga rasio tersebut berhubungan langsung dengan core business bank yaitu Aset, Modal, Pendapatan dan Keuntungan.

Tulisan ini juga menggunakan kerangka Studi Pra-Pandemi (2010-2019) untuk mengetahui keadaan dan pertumbuhan laba prapandemi yang sebenarnya. Karena adanya kontradiksi hasil penelitian pda topik ini, maka penelitian ini mengambil judul "Kontribusi Profitabilitas Terhadap Pertumbuhan Laba PT. Bank Rakyat Indonesia (Persero), Tbk".

\section{KAJIAN PUSTAKA DAN PENGEMBANGAN HIPOTESIS \\ Agency theory dan Pertumbuhan laba}

Teori keagenan adalah kontrak antara manajer (agent) dan pemilik (principal). Pemilik mempekerjakan manajer untuk menjalankan bisnis, dan agen diberi imbalan atas tindakan mereka (Jensen \& Meckling, 1976). Untuk memfasilitasi hubungan kontraktual ini, dewan komisaris memberikan wewenang ini kepada manajemen puncak, tujuannya agar manajemen puncak menjalankan bisnis dan menghasilkan 
keuntungan yang tinggi, dan dewan untuk mengawasi pelaksanaannya (Kurniawansyah, 2018). Inti dari teori keagenan adalah desain kontrak, yang disesuaikan dengan kepentingan manajemen dan pemilik jika terjadi konflik kepentingan (Aljana \& Purwanto, 2017).

Perusahaan yang tumbuh memiliki tingkat pertumbuhan laba yang lebih tinggi daripada perusahaan yang tidak tumbuh dan dapat menggunakan pertumbuhan laba sebagai insentif karena peluang investasi yang lebih baik di periode berikutnya, dengan asumsi penguatan hubungan antara ukuran perusahaan, DER dan profitabilitas (Wahyuni, Kepramareni, \& ..., 2020)

\section{Keterkaitan antara Agency theory dan Pertumbuhan laba}

Keuangan perusahaan akan menginformasikan seberapa baik kinerja bisnis perusahan. Hal tersebut berarti kesepakatan dan penentuan untuk keuntungan bersama antara pemilik dan pemilik bisnis. Seiring dengan desain kontrak yang tepat untuk mensinkronkan kepentingan manajemen dan pemilik. Hal ini merupakan inti dari teori Agency.

\section{Pertumbuhan Laba}

Pertumbuhan laba merupakan rasio kemampuan perusahaan untuk meningkatkan laba dibandingkan tahun sebelumnya (Sundari \& Satria, 2021). Pertumbuhan laba usaha yang baik menunjukkan bahwa usaha tersebut dalam kondisi keuangan yang baik, yang pada gilirannya akan meningkatkan nilai usaha. Tingkat pertumbuhan laba adalah tingkat kenaikan laba yang dibuat oleh bisnis. Pertumbuhan laba dapat dihitung dengan menggunakan rumus berikut.(Sundari \& Satria, 2021)

Pertumbuhan Laba $=\underline{\text { Laba Tahun }}$ berjalan - laba tahun sebelumnya $\mathrm{x}$ $100 \%$

\section{Laba tahun sebelumnya}

\section{Profitabilitas}

Menurut (Kusuma et al., 2019), profitabilitas adalah kemampuan untuk mendapatkan keuntungan melalui bisnis dengan menggunakan dana dari aset yang dimiliki oleh perusahaan. Definisi lain dari profitabilitas adalah kemampuan suatu perusahaan untuk memperoleh keuntungan yang berkaitan dengan penjualan, total aset, dan modal (Oktary \& Muliani, 2020). Dalam penelitian ini, penulis menggunakan ROA, ROE, dan NPM sebagai proxy analisis.

\section{Return ON Asset (ROA)}

Return on asset (ROA) adalah tingkat pengembalian yang menunjukkan kemampuan perusahaan dalam menghasilkan keuntungan dari aset yang digunakan (Almira \& Wiagustini, 2020). Semakin tinggi rasio ini maka semakin baik kinerja perusahaan (Suwardika \& Mustanda, 2017). ROA dihitung dengan rumus sebagai berikut: (Suwardika \& Mustanda, 2017)

\section{Return on assets $=$ Laba setelah pajak $\mathrm{x} 100 \%$}

Total assets

Return on total assets (ROA) diprediksikan memiliki hubungan yang positif dan signifikan. Semakin baik return on assets (ROA), maka semakin tinggi pula tingkat pertumbuhan laba perusahaan. Hal ini sesuai dengan penelitian yang menunjukkan bahwa ROA berdampak positif terhadap pertumbuhan laba (Sundari \& Satria, 2021) dan (Sari \& Idayati, 2019).

\section{Return On Equity (ROE)}

Return on Equity adalah pengembalian yang diberikan kepada investor atas dana yang diinvestasikan untuk kelangsungan bisnis. Investor berperan penting dalam menyediakan dan melengkapi pembiayaan pengembangan usaha (Dari, Wahono, \& Mustapita, 2018). Rasio ini mengukur kemampuan perusahaan untuk menghasilkan keuntungan berdasarkan modal saham yang diberikan (Sanjaya \& Rizky, 2018). Return on Equity dihitung dengan rumus sebagai berikut: (Sanjaya \& Rizky, 2018)

$$
\begin{aligned}
& \text { Return on equity }=\text { laba bersih } \\
& \mathrm{x} 100 \%
\end{aligned}
$$

Modal saham

Return on equity diprediksi memiliki hubungan positif dan signifikan. Semakin baik ROE, semakin besar pertumbuhan laba. Hal ini sesuai dengan penelitian (Dari et al., 2018) yang menyatakan bahwa ROE berpengaruh positif terhadap pertumbuhan laba.

\section{Net Profit Margin (NPM)}

Net profit margin (NPM) merupakan salah satu rasio yang digunakan untuk mengukur 
profitabilitas suatu perusahaan dengan membandingkan laba bersih setelah pajak dengan pendapatan penjualan (Tarumasely \& Siswati, 2021). Semakin tinggi margin laba bersih, semakin baik. Net Profit Margin diukur dengan rumus sebagai berikut: (Safitri \& Mukaram, 2018)

Net profit margin $=\underline{\text { Laba setelah pajak }}$ $\mathrm{x} 100 \%$

\section{Penjualan}

Net Profit Margin (NPM) diprediksi memiliki hubungan positif dan signifikan. Semakin baik NPM, semakin tinggi tingkat pertumbuhan laba bisnis Anda. Hal ini sesuai dengan penelitian (Safitri \& Mukaram, 2018) dan (Susyana \& Nugraha, 2021) yang menunjukkan bahwa NPM berdampak positif terhadap pertumbuhan laba. Dari uraian di atas, dapat diambil kerangka pemikiran sebagai berikut :

\section{Gambar 1. Kerangka Pikir Penelitian}

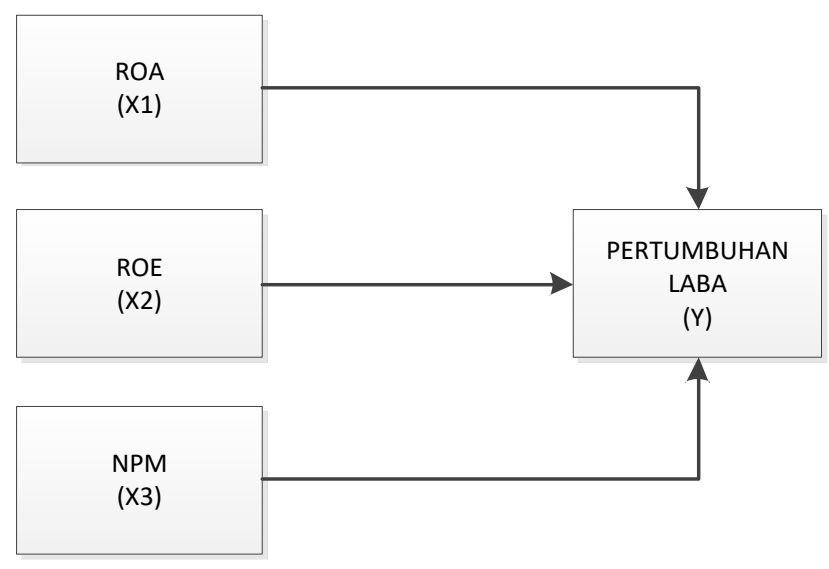

Sumber : pengembangan hipotesis (2021)

\section{Hipotesis Penelitian}

Berdasarkan kajian teori dan kerangka berfikir, hipotesis pada penelitian ini adalah sebagai berikut

a. Return on assets (ROA) berpengaruh positif signifikan terhadap pertumbuhan laba PT. BRI (Persero), Tbk

b. Return on Equity (ROE) berpengaruh positif signifikan terhadap pertumbuhan laba PT. BRI (Persero), Tbk c. Net Profit Margin (NPM) berpengaruh positif signifikan terhadap pertumbuhan laba PT. BRI (Persero), Tbk

\section{METODE PENELITIAN}

Dalam penelitian ini, penulis menggunakan pendekatan kuantitatif, yaitu penelitian dengan data yang terstruktur dan digeneralisasikan (Kurniawan \& Puspitaningtyas, 2016). Metode yang digunakan adalah eksplanatori, yaitu suatu metode penelitian yang digunakan untuk mencari penjelasan atas suatu fenomena, masalah atau perilaku yang dihadapi. Penelitian ekspalanatori dilakukan untuk menemukan penjelasan penyebab kejadian tersebut (Priyono, 2016). Penelitian ini dilakukan untuk mengetahui pengaruh ROA, ROE, NPM terhadap pertumbuhan laba PT. Bank Rakyat Indonesia (Persero), Tbk. Variabel terikat (Y) dalam penelitian ini adalah Perubahan Laba Bank Rakyat Indonesia. Variabel bebas (X) dalam penelitian ini menggunakan variabel ROA (X1), ROE (X2), dan NPM (X3).

Menggunakan Data sekunder berupa laporan keuangan yang diunduh dari website www.bri.co.id, data dianalisis secara time series per triwulan mulai tahun 2010 hingga 2019. Dengan demikian, total data yang diamati adalah 40 data observasi. Data diolah menggunakan bantuan software Microsoft Excel 2013 dan SPSS versi 21

\section{HASIL PENELITIAN DAN} PEMBAHASAN Analisis Regresi Linier Berganda

Analisis regresi linier berganda adalah model regresi linier dengan satu variabel terikat dan (dua atau lebih) variabel bebas (Harlan, 2018) dan menggunakan persamaan berikut: $\mathbf{Y}=$ $a+b 1 X 1+b 2 X 2+b 3 X 3+b n X n+e$. 
Tabel 2 Analisis Regresi Linear Berganda

\begin{tabular}{|l|r|r|r|r|r|}
\hline \multicolumn{7}{|c|}{ Coefficients $^{\text {a }}$} & Sig. \\
& \multicolumn{7}{|c|}{$\begin{array}{c}\text { Unstandardized } \\
\text { Coefficients }\end{array}$} & $\begin{array}{c}\text { Standar } \\
\text { dized } \\
\text { Coeffici } \\
\text { ents }\end{array}$ & t & \\
\cline { 2 - 6 } & $\mathrm{B}$ & $\begin{array}{c}\text { Std. } \\
\text { Error }\end{array}$ & Beta & & \\
\hline (Constant) & $-11,790$ & 11,079 & & $-1,064$ &, 294 \\
\hline ROA & $-2,107$ & 5,400 &,- 138 &,- 390 &, 699 \\
\hline ROE & 1,951 &, 683 &, 716 & 2,856 &, 007 \\
\hline NPM & 1,055 & 1,324 &, 179 &, 797 &, 431 \\
\hline a. Dependent Variable: PERTUMBUHAN LABA \\
\hline
\end{tabular}

Sumber : data penelitian diolah (2021)

Dari tabel diatas, diperoleh persamaan sebagai berikut : $\mathbf{Y}=\boldsymbol{\alpha}+\boldsymbol{\beta} 1 \mathbf{X} 1+\boldsymbol{\beta} 2 \mathbf{X} 2+\boldsymbol{\beta 3} \mathbf{X 3}+\mathbf{e}$.

$\mathrm{Y}=-11,790_{\text {(Konstanta) }}-2,107$ (ROA) $+1,951_{(\mathrm{ROE})}+$ $4,371+1,055_{(\mathrm{NPM})}(\mathrm{e})$

Dari persamaan regresi tersebut dapat dijelaskan sebagai berikut.

1. Konstanta -11.790 menunjukkan bahwa Pertumbuhan Laba (Y) adalah -11.790 ketika ROA (X1), ROE (X2) dan NPM (X3) adalah 0 .

2. koefisien ROA (X1) sebesar -2.107 menunjukkan bahwa untuk setiap kenaikan 1\% ROA (X1), Pertumbuhan Laba (Y) menurun sebesar 2.107 jika variabel lainnya tidak berubah.

3. Koefisien ROE (X2) sebesar 1,951 menunjukkan bahwa Pertumbuhan Laba (Y) meningkat sebesar 1,951 untuk setiap $1 \%$ tambahan ROE (X2) jika tidak ada variabel lain yang berubah.

4. Koefisien NPM (X3) sebesar 1,055 menunjukkan bahwa Pertumbuhan Laba (Y) meningkat sebesar 1,055 untuk setiap $1 \%$ NPM (X3) jika tidak ada variabel lain yang berubah.

\section{Analisis Koefisien Determinasi}

Uji koefisien determinasi (R2) dari varians atau rasio varians yang dapat dijelaskan oleh model (Harlan, 2018). Hasil uji koefisien adalah sebagai berikut:
Tabel 3 Model Fit

\begin{tabular}{|c|c|c|c|c|}
\hline \multicolumn{5}{|c|}{ Model Summary } \\
\hline Model & $\mathrm{R}$ & $\begin{array}{c}\mathrm{R} \\
\text { Square }\end{array}$ & $\begin{array}{c}\text { Adjusted R } \\
\text { Square }\end{array}$ & $\begin{array}{l}\text { Std. Error of } \\
\text { the Estimate }\end{array}$ \\
\hline 1 &, $688^{\mathrm{a}}$ &, 474 &, 430 & 2,54390 \\
\hline
\end{tabular}

Sumber : data penelitian diolah (2021)

Dari data pada tabel ringkasan model, kita dapat melihat bahwa koefisien determinasi (R2) adalah 0,474 atau $47,4 \%$. Hal ini karena pertumbuhan penjualan (Y) dapat dipengaruhi oleh ROA (X1), ROE (X2) dan NPM (X3), sedangkan sisanya 52,6\% tidak dijelaskan dalam model penelitian. Artinya dipengaruhi oleh faktor lain.

\section{UJi F (Simultan)}

Uji F dilakukan untuk mengevaluasi apakah model yang dianalisis memenuhi persyaratan kelayakan model (model fit). Dasar dari proses pengambilan keputusan telah ditunjukkan. Artinya, jika nilainya Fhitung > Ftabel, maka Dinyatakan memenuhi syarat untuk analisis lebih lanjut. Hasil pengujian ada pada tabel berikut ini.

\section{Tabel 4 Uji F}

\begin{tabular}{|l|c|r|r|r|r|}
\hline \multicolumn{7}{|c|}{ ANOVA $^{\text {a }}$} \\
\hline Model & $\begin{array}{c}\text { Sum of } \\
\text { Squares }\end{array}$ & df & $\begin{array}{c}\text { Mean } \\
\text { Square }\end{array}$ & F & Sig. \\
\hline Regression & 209,929 & 3 & 69,976 & 10,813 &, $000^{\mathrm{b}}$ \\
\hline Residual & 232,971 & 36 & 6,471 & & \\
\hline Total & 442,900 & 39 & & & \\
\hline a. Dependent Variable: PERTUMBUHAN LABA \\
\hline
\end{tabular}

Sumber : data penelitian diolah (2021)

\section{Uji T (Parsial)}

Uji statistik pada dasarnya menunjukkan seberapa efektif variabel penjelas (independen) dalam menjelaskan variasi variabel dependen. Signifikansi uji statistik adalah $=5 \%$. Kriteria pengujian hipotesis menggunakan statistik $t$ adalah signifikansi (p-value) dari t dan hipotesis alternatif diterima jika $\alpha<0,05$. Hal ini menunjukkan bahwa variabel independen memiliki pengaruh yang besar terhadap variabel dependen.

Hasil pengujian T (t-test) adalah sebagai berikut: 


\section{Tabel 5 Uji T}

\begin{tabular}{|l|r|r|r|r|r|}
\hline \multicolumn{7}{|c|}{ Model } & \multicolumn{7}{|c|}{ Coefficients $^{\text {a }}$} \\
& \multicolumn{2}{|c|}{$\begin{array}{c}\text { Unstandardized } \\
\text { Coefficients }\end{array}$} & $\begin{array}{c}\text { Standar } \\
\text { dized } \\
\text { Coeffic } \\
\text { ients }\end{array}$ & t & Sig. \\
\cline { 2 - 6 } & $\mathrm{B}$ & $\begin{array}{c}\text { Std. } \\
\text { Error }\end{array}$ & Beta & & \\
\hline (Constant) & $-11,790$ & 11,079 & & $-1,064$ &, 294 \\
\hline ROA & $-2,107$ & 5,400 &,- 138 &,- 390 &, 699 \\
\hline ROE & 1,951 &, 683 &, 716 & 2,856 &, 007 \\
\hline NPM & 1,055 & 1,324 &, 179 &, 797 &, 431 \\
\hline a. Dependent Variable: PERTUMBUHAN LABA \\
\hline
\end{tabular}

Sumber : data penelitian diolah (2021)

Berdasarkan hasil pengujian di atas, kita dapat menginterpretasikan sebagai berikut :

Pengaruh ROA (X1) terhadap Pertumbuhan Laba (Y).

Kriteria pengujian uji t pada tabel diatas, diperoleh t-hitung sebesar $-0,390$,nilai p-value sebesar 0.699 diatas 0.05 dan derajat bebas $=40$, maka diperoleh t-tabel sebesar 2,0210. Oleh karena itu, hasil nilai $\mathrm{t}_{\text {-hitung }}<\mathrm{t}$-tabel $(0,390<$ 2,0210) dan nilai signifikan lebih besar dari pvalue 0.05 atau $0.699>0.05$, maka dinyatakan $\mathrm{HO}$ diterima dan $\mathrm{Ha}$ ditolak. Nilai Koefisien regresi variabel ROA adalah - 0.138 (Negatif). Hal ini berarti ROA (X1) tidak berpengaruh dan tidak signifikan terhadap Pertumbuhan Laba (Y).

Semakin tinggi nilai ROA, semakin rendah pertumbuhan laba Bank Rakyat Indonesia periode 2010-2019. Ini berarti bahwa Bank Rakyat Indonesia belum dapat menggunakan sumber dayanya untuk menghasilkan keuntungan. Begitu banyak investasi asset yang telah dilakukan periode 2010-2019, ternyata belum mampu untuk menstabilkan pertumbuhan laba perusahaan. Oleh karena itu, aset perusahaan yang sudah ada wajib dimaksimalkan.

Temuan ini tidak mengkonfirmasi bahwa ROA berdampak positif terhadap pertumbuhan laba (Sundari \& Satria, 2021) dan (Sari \& Idayati, 2019), tetapi penelitian (Safitri \& Mukaram, 2018); (Dari et al., 2018) dan (Susyana \& Nugraha, 2021) menyatakan ROA tidak mempengaruhi pertumbuhan laba.

\section{Pengaruh ROE (X2) terhadap Pertumbuhan Laba (Y).}

Kriteria pengujian uji t pada tabel diatas, diperoleh t-hitung sebesar 2,856 dan nilai p- value sebesar 0.007 lebih kecil dari 0.05 dan derajat bebas $=40$, maka diperoleh t-tabel sebesar 2.0210. Oleh karena itu, hasil nilai $t$-hitung $>t_{\text {-tabel }}$ $(2,856>2,0210)$ dan nilai signifikan lebih kecil dari p-value 0.05 atau $0.007<0.05$, maka dinyatakan Ha diterima dan Ho ditolak. Nilai Koefisien regresi variabel $\mathrm{ROE}$ adalah 0.716 (Positif). Hal ini berarti ROE (X2) berpengaruh positif dan signifikan terhadap Pertumbuhan Laba (Y).

Semakin tinggi ROE, semakin besar pertumbuhan laba Bank Rakyat Indonesia periode 2010-2019. Hal ini dikarenakan modal yang digunakan untuk operasi tersebut tepat sasaran. Bank Rakyat Indonesia dapat mengembalikan dana kepada investor melebihi modal awal yang diberikan. Kondisi ini disebabkan karena Bank Rakyat Indonesia menghasilkan laba dari satu periode ke periode lainnya, walau belum konsisten.

Penelitian ini tidak mengkonfirmasi pernyataan bahwa ROE tidak mempengaruhi pertumbuhan laba (Safitri \& Mukaram, 2018) dan (Sundari \& Satria, 2021), tetapi (Dari et al., 2018) Mengkonfirmasi pertumbuhan laba berdasarkan hasil penelitiannya.

\section{Pengaruh NPM (X3) terhadap Pertumbuhan Laba (Y). \\ Kriteria pengujian uji t pada tabel diatas,} diperoleh t-hitung sebesar 0,797 dan nilai pvalue sebesar 0.431 lebih besar dari 0.05 dan derajat bebas $=40$, maka diperoleh t-tabel sebesar 2.0210. Oleh karena itu, hasil nilai $\mathrm{t}_{\text {-hitung }}<\mathrm{t}$-tabel $(0,797<2,0210)$ dan nilai signifikan lebih besar dari p-value 0.05 atau $0.431>0.05$, maka dinyatakan Ho diterima dan Ha ditolak. Nilai Koefisien regresi variabel NPM adalah 0.179 (Positif). Hal ini berarti NPM (X3) tidak berpengaruh dan tidak signifikan terhadap Pertumbuhan Laba (Y).

Semakin tinggi NPM, semakin tinggi pula tingkat pertumbuhan laba Bank Rakyat Indonesia periode 2010-2019. Hal ini karena bisnis memiliki kemampuan untuk meningkatkan laba di samping biaya yang dikeluarkan. Bank Rakyat Indonesia mampu mengkonversi Pendapatan perusahaan walau ditengah meningkatnya biaya operasional perusahaan. Manajemen Bank Rakyat Indonesia wajib untuk mempertahankan kondisi ini. 
Hasil penelitian ini tidak mendukung hasil (Sari \& Idayati, 2019) yang menunjukkan bahwa NPM berpengaruh negatif terhadap pertumbuhan laba, tetapi penelitian (Safitri \& Mukaram, 2018) dan (Susyana \& Nugraha, 2021) menunjukkan bahwa NPM memiliki dampak positif pada pertumbuhan laba.

\section{KESIMPULAN}

Berdasarkan hasil pengujian data dengan menggunakan analisis regresi berganda, maka dapat disimpulkan bahwa:

a. ROA berdampak negatif terhadap pertumbuhan laba PT. BRI (Persero), Tbk. Selama periode 2010-2019, semakin tinggi ROA, semakin rendah nilai pertumbuhan laba. Hal ini dapat diartikan sebagai perusahaan tidak dapat menggunakan asetnya untuk menghasilkan keuntungan dari pendapatannya.

b. ROE berpengaruh positif signifikan terhadap pertumbuhan laba PT. BRI (Persero)., Tbk. Selama periode 2010-2019, semakin tinggi nilai ROE maka semakin tinggi pula nilai pertumbuhan laba. Perusahaan dapat membayar investor lebih besar dari modal awal yang diberikan. Kondisi ini menggambarkan perusahaan dapat memperoleh keuntungan dari satu periode ke periode berikutnya.

c. NPM berpengaruh positif signifikan terhadap pertumbuhan laba PT. BRI (Persero). , Tbk. Periode 2010 hingga 2019. Semakin tinggi nilai NPM maka pertumbuhan laba semakin besar. Hal ini karena perusahan dapat meningkatkan keuntungan selain biaya yang dikeluarkan oleh operasional bisnis.

\section{REFERENSI}

Ainun, N., Murtani, A., \& Hutagalung, M. A. K. (2020). Analisis Faktor-Faktor Yang Mempengaruhi Loyalitas Nasabah Pada PT. Bank Muamalat Indonesia. Tbk Cabang Balai Kota Medan. Jurnal Mahasiswa Fakultas Ekonomi Dan Bisnis, 1(1), 355366.

Aljana, B., \& Purwanto, A. (2017). PENGARUH PROFITABILITAS, $\quad$ STRUKTUR KEPEMILIKAN DAN KUALITAS AUDIT TERHADAPMANAJEMEN
LABA (Studi pada Perusahaan Manufaktur yang Terdaftar di Bursa Efek Indonesia Tahun 2013-2015). Diponegoro Journal of Accounting, 6(3), 207-221.

Almira, N. P. A. K., \& Wiagustini, N. L. P. (2020). Return on Asset, Return on Equity, Dan Earning Per Share Berpengaruh Terhadap Return Saham. E-Jurnal Manajemen Universitas Udayana, 9(3), 1069.

https://doi.org/10.24843/ejmunud.2020.v09 i03.p13

Asnawi, W. A., Rate, P. Van, Sam, U., \& Manado, R. (2018). Pengaruh Kinerja Keuangan Bank Terhadap Return on Asset (Roa) Studi Pada Bank Umum Devisa Buku 4. Jurnal EMBA: Jurnal Riset Ekonomi, Manajemen, Bisnis Dan Akuntansi, 6(4), 2898-2907. https://doi.org/10.35794/emba.v6i4.21198

Dari, N. W., Wahono, B., \& Mustapita, A. F. (2018). Pengaruh Return On Asset (ROA), Return On Equity (ROE) terhadap Pertumbuhan Laba dengan Good Corporate Governance Sebagai Variabel Pemoderasi. E-Jurnal Riset Manajemen, 162-180.

Fadella, F. F., Dewi, R. R., \& Fajri, R. N. (2020). ANALISIS FAKTOR-FAKTOR YANG MEMPENGARUHI PERTUMBUHAN LABA. Jurnal Akuntansi Dan Keuangan, 11(2), 12. https://doi.org/10.36448/jak.v11i2.1521

Fadila, R., \& Saifi, M. (2018). Pengaruh Earning Per Share (EPS), Return On Equty (ROE) Dan Net Profit Margin Terhadap Harga Saham Perusahaan Industri Barang Konsumsi yang Terdaftar di Bursa Efek Indonesia. Jurnal Administrasi Bisnis, 61(3), 154-162.

Harlan, J. (2018). Analisis Regresi Linear. Gunadarma (Vol. 53). Jakarta: Gunadarma.

Ikhwal, N. (2016). Analisis Roa Dan Roe Terhadap Profitabilitas Bank Di Bursa Efek Indonesia. Al-Masraf: Jurnal Lembaga Keuangan Dan Perbankan, 1(2), 211-227. Retrieved from http://journal.febi.uinib.ac.id/index.php/al masraf/article/view/57

Jensen, M. C., \& Meckling, W. H. (1976). Theory of the Firm : Managerial Behavior, Agency Costs and Ownership Structure. Journal of 
Financial Economics, 3, 305-360. https://doi.org/doi:10.1016/0304405X(76)90026-X

Kurniawan, A. W., \& Puspitaningtyas, Z. (2016). Metode Penelitian Kuantitatif. (1, Ed.) (Vol. 4). Yogyakarta: PANDIVA BuKu. https://doi.org/http://dx.doi.org/10.1007/97 8-1-4419-8580-4_5

Kurniawansyah, D. (2018). Teori Agency Dalam Pemikiran Organisasi ; Pendekatan Positivist Dan Principle-Agen. Jurnal Riset Akuntansi Dan Bisnis Airlangga, 3(2), 435446.

https://doi.org/10.31093/jraba.v3i2.122

Kusuma, G. I., Suhadak, \& Arifin, Z. (2019). Analisis pengaruh profitabilitas dan tingkat pertumbuhan terhadap struktur modal dan nilai perusahaan. Jurnal Bisnis Dan Akuntansi, (1), 1-15.

Likha, M., \& Fitria, A. (2019). Pengaruh Pertumbuhan Laba, Kinerja Keuangan Terhadap Nilai Perusahaan Dimoderasi Corporate Social Responsibility. Jurnal Ilmu Dan Riset Akuntansi, 8(5), 1-19.

Oktary, D., \& Muliani. (2020). Pengaruh Rasio Profitabilitas Terhadap Nilai Perusahaan Sektor Industri Barang Konsumsi Yang Terdaftar Di Bursa Efek Indonesia Tahun 2015-2017. Jurnal Ekonomi Integra, 10(2), 186. https://doi.org/10.51195/iga.v10i2.145

Priyono. (2016). Metode Penelitian Kuantitatif. (T. Chandra, Ed.) (1st ed.). ZIFATAMA PUBLISHING.

PT Bank Rakyat Indonesia. (2019). Annual Report Bank Rakyat Indonesia 2019. Jakarta. Retrieved from https://bri.co.id/documents/20123/56786/A nnual Report Bank Rakyat Indonesia 2019 OK.pdf

Putriana, M. (2016). FAKTOR-FAKTOR YANG MEMPENGARUHI PERTUMBUHAN LABA. Eksis, 7(1), 53-68. https://doi.org/http://dx.doi.org/10.33087/e ksis.v7i1.5

Safitri, A. M., \& Mukaram, M. (2018). Pengaruh ROA, ROE, dan NPM Terhadap Pertumbuhan Laba Pada Perusahaan Sektor Industri Barang Konsumsi Yang Terdaftar di Bursa Efek Indonesia. Jurnal Riset Bisnis Dan Investasi, 4(1), 25. https://doi.org/10.35697/jrbi.v4i1.990
Sanjaya, S., \& Rizky, M. F. (2018). Analisis Profitabilitas Dalam Menilai Kinerja Keuangan Pada PT. Taspen (Persero) Medan. KITABAH, 2(2), 37-39.

Sari, M. P., \& Idayati, F. (2019). Pengaruh Rasio Keuangan Terhadap Pertumbuhan Laba Pada Perusahaan Sektor Properti dan Real Estate Di Bursa Efek Indonesia. Jurnal Ilmu Dan Riset Akuntansi, 8, 5.

Septiani, T. A., Siswantini, T., \& Murtatik, S. (2021). Pengaruh Likuiditas, Leverage Dan Profitabilitas Terhadap Financial Distress Pada Sektor Industri Barang Konsumsi Yang Terdaftar Di Bei the Effect of Liquidity, Leverage, and Profitability on Financial Distress in the Consumption Industry Sector Listed on. Jurnal Apresiasi Ekonomi, 9(1), 100-111. Retrieved from www.idx.com

Sundari, R., \& Satria, M. R. (2021). Pengaruh Return on Asset Dan Return on Equity Terhadap Pertumbuhan Laba Pada Perusahaan Sub Sektor Wholesale Yang Terdaftar Di Bursa Efek Indonesia. Land Journal, 2(1), 107-118. https://doi.org/10.47491/landjournal.v2i1.1 122

Susyana, F. I., \& Nugraha, N. M. (2021). Pengaruh Net Profit Margin, Return on Assets, Dan Current Ratio Terhadap Pertumbuhan Laba. Jurnal Ekonomi Manajemen Perbankan, 3(1), 56-69.

Suwardika, I. N. A., \& Mustanda, I. K. (2017). Pengaruh Leverage, Ukuran Perusahaan, Pertumbuhan Perusahaan, Dan Profitabilitas Terhadap Nilai Perusahaan Pada Perusahaan Properti. E-Jurnal Manajemen Unud, 6(3), 1248-1277.

Tarumasely, S., \& Siswati, S. (2021). Analisis Rasio Profitabilitas Pada PDAM Tirta Merapi Kabupaten Klaten Berdasarkan Operating Profit Margin, Net Profit Margin , Return On Asset dan Return On Equity Penelitian ini dilakukan untuk mengetahui analisis rasio profitabilitas PDAM Tirta Merapi. Equilibrium Jurnal Bisnis \& Akuntansi, XV(1), 70-81.

Wahyuni, N. K. S., Kepramareni, P., \& ... (2020). PENGARUH PERTUMBUHAN LABA, UKURAN PERUSAHAAN DAN DEBT EQUITY RATIO TERHADAP 
PROFITABILITAS PADA PERUSAHAAN PERBANKAN YANG TERDAFTAR DI BURSA EFEK INDONESIA. Jurnal Kharisma, 2(3), 33-
48. Retrieved from http://ejournal.unmas.ac.id/index.php/kharisma/art icle/view/1483 